\title{
Legal Regulation of Microfinance Institutions as NGOs Following the Judgment of the Constitutional Court
}

\author{
Submitted 16/06/20, $1^{\text {st }}$ revision $25 / 07 / 20$, $2^{\text {nd }}$ revision 29/08/20, accepted 12/09/20
}

Diamanta Sojeva $^{1}$, Armand Krasniqi ${ }^{2}$, Mejdi Bektashi ${ }^{3}$

\begin{abstract}
:
Purpose: This research analysizes the legal effects that may have in the future Judgment of the Constitutional Court of Kosovo on the inadmissibility of some provisions of the Law in the banking sector.

Design/Methodology/Approach: In the study we dealt with the statistics of microfinance in institutions such as NGOs and also addressed the decision of the constitutional court regarding the law on banks, microfinance institutions, and non-bank financial institutions.

Findings: It is found that, even after the decision of the court, inconsistencies continue to emerge between the functional and operational objectives of MFI - NGOs with those of the Central Bank of Kosovo and the Ministry of Public Administration.

Practical Implications: What is considered unclear in this situation is the negligence of state institutions to amend and synchronize a series of legal acts that should more clearly regulate the position and function of MFI - NGOs in the spirit of the Court Judgment Constitutional of Kosovo.
\end{abstract}

Originality/Value: In reality, this situation presents many legal uncertainties for these entities.

Keywords: Legislation, non-governmental organizations, microfinance institutions, lending, financing.

JEL Codes: K20, K23

Article Type: Research study.

${ }^{I}$ Teaching assistant at Faculty of Economics, University of Pristina, Kosovo,

e-mail:diamanta.sojeva@uni-pr.edu;

${ }^{2}$ Professor at Faculty of Economic, University of Pristina, Kosovo

e-mail: armand.krasniqi@uni-pr.edu;

${ }^{3}$ Professor at Faculty of Law, University of Pristina, Kosovo

e-mail: mejdi.bektashi@uni-pr.edu; 


\section{Introduction}

Since 2010, relevant Kosovar institutions have undertaken a series of measures to seriously review the legal system affecting non-profit organizations whose activities are focused on financing and lending to individuals and family businesses.

Contrary to the trends that characterize the MFI - NGOs in certain countries and in the Balkans, the situation in Kosovo is different. Influenced by a systematic denigration campaign by individuals and interest groups, through print and electronic media, a perception has emerged that these are "robbery", "usury", etc., organizations that exercise their activity to the detriment of citizens.

Motivated by these worldviews and perhaps by the greed to transform or launder these organizations' funds, two attempts have so far been made to achieve this goal. First, in 2012 the Central Bank of Kosovo sent to the Assembly of Kosovo the law for Bank Approval, Microfinance Institutions and Non-bank Financial Institutions no. 04 / L093 to which the Constitutional Court by Judgment declares inadmissible Articles: 90, 95 (1.6), 110, 111 and 116 and in contradiction with the Constitution these provisions related precisely to the deregulation of MFI - NGO ( Constitutional Court, 2013).

Second, after the failure of the above law, it is intended that by amending the Law on Freedom of Association in Non-Governmental Organizations a legal basis will be created which will enable the created capital of MFI-NGOs to be transferred to private entities and perhaps to the budget of the Ministry of Administration. So far, these two initiatives have remained unfinished. The issue that is currently being overlooked is whether all state institutions should be careful about the legal regulation of MFI NGOs in the spirit of the Judgment of the Constitutional Court of Kosovo or for certain interests should act differently. In our view, the Judgment of the Constitutional Court is binding on all institutions as it confirms the legality within the legislative framework of these organizations

Previous researchers have evolved and according to them there are various institutions that help people below the poverty line and small business start-up initiatives to have small loans to meet their goals. The microfinance model is about the constitution of the Self-Help Group (SHG) associated with the banking program (BP). This connection results in the creation of a subject - autonomous society of united people to voluntarily fulfill the needs of ordinary people. Also, from this point of view, the goals of the MFIs focus on meeting several goals to provide microfinance (Nayak and Silva, 2019).

It has been proven that microfinance is the mean to help the poor families and small business start-up initiatives and to contribute to the country's economy by increasing its income generation capacity. Due to some advantages offered by microfinance institutions (MFIs) compared to commercial banks, the number of people and 
businesses receiving loans in these institutions is increasing. The amount of loans issued by MFIs in Kosovo has reached over EUR 150 million, while a significant percentage of these loans are loans for enterprises. According to data released by the Association of Microfinance Institutions of Kosovo, there are over 77,000 borrowers who have addressed to these institutions.

Microcredit is an opportunity for the people to realize their dreams and a strategic tool to reduce poverty and help the poor people to participate in the social and economic life of a country. Microfinance helps families not only to meet their current needs, but also to plan accordingly for their better future (Bank of Turkey, 2018).

Thus, microfinance plays a solid role in the development of the Kosovar economy in the following ways:

Loan for Rural Poor - financial institutions meet the needs of the poor people by providing microfinance. Rural people rely on non-institutional agencies to accomplish their financial goals. Microfinance takes care of the needs of poor people and makes them economically and socially more stable.

Poverty Reduction Tool - with the help of microfinance people are able to secure employment which helps them to have a good income and consequently to reduce poverty (Bank of Turkey, 2018).

Empowering women - women's economic empowerment refers to improving their economic status by giving them the freedom to exercise their rights in a proper way. Thus, microfinance helps poor women grow economically (Stavrevska, 2018).

Economic Growth and Development - with the aim of economic growth and development financing plays a vital role. This increase leads to GDP and economic as well as in the development of the country (Isabel Sainz-Fernandez and SanfilippoAzofra, 2018).

Savings Mobilization - saving is the main source to fulfill the contingencies. Microfinance is a useful tool that develops saving habits among people. Finances created through savings are used for lending. Thus, microfinance helps to mobilize savings (Khachatryan and Vardan Baghdasaryan Valentina Hartarska, 2019).

Skills development - microfinance helps the employment of poor people. It also support people to create their own businesses and motivate them to do this. Microfinance encourages its members to jointly or individually set up business units. The microfinance institutions also provide trainings in accordance with the circumstances on how to operate in business fields. Thus microfinance plays a vital role for skill development (Güngen, 2018). 
Mutual assistance and cooperation - microfinance is a helping and collaborative tool for these poor and needy people. People can easily face economic crises if they have the availability of microfinance.

Social Welfare - microfinance also helps create employment. This employment also helps to increase people's income level. They can go for better education, health, family welfare etc. So micro finance helps in social welfare (Singh and Agrawal, 2018).

\subsection{Availability of Loans and Bank Facilities for the Weak Segment of the Society}

Currently, in Kosovo there are mainly two models for providing microfinance in Kosovo. MFIs models registered as business entities and certified by the Central Bank and MFIs in quality of NGOs established under the Law on Freedom of Association in Non-Governmental Organizations and also certified and controlled by the Central Bank.

The concept of microfinance in Kosovo is known only after the 2000s. Here different models were used to provide microfinance as there is no specific model that fits for all conditions. Each model has to be modified according to different situations and local requirements. To this end, Microfinance Institutions have adopted various model distributions and can be categorized into broad categories.

\section{Methodology}

The study is mainly based on the interpretation of the effect of legal norms from primary data. The primary data mainly relate to the case file from which the Judgment of the Constitutional Court of Kosovo came out regarding the incompatibility of some provisions of the Law on Banks, Microfinance Institutions and Non-bank Financial Institutions no. 04 / L-093 and from the draft Law on Freedom of Association in NonGovernmental Organizations. The study is also complemented by data collected through book references, recent research publications available on various websites and journals, newspapers, Research Articles, Dissertations, Standard Edition, EJournals, periodicals, online, Report and data from the Association of Microfinance Institutions of Kosovo, Microfinance Institution (development and regulation), etc.

\section{Findings and Discussions}

\subsection{A Brief Background to the Core of the MFIs - NGOs Problem in Kosovo}

A number of Non-Governmental Organizations specifically plan and implement microfinance activities (MFI-NGOs). They have become popular in the world, usually extending to developing countries including our region. In reality, the operating model in Kosovo is similar to other countries, where interest rates are relatively high in order to cover the costs of financing, the degree of credit risk for small and often informal 
businesses and administrative lending cost, which is obviously higher for small loans. Microfinance Institutions (MFIs) in Kosovo started their activity after the war as financial assistance and programs to support the small business initiatives. Their legal basis was derived from UNMIK Regulations.

Undoubtedly, their contribution has been important in initiating post-war economic growth, when the financial sector was almost inexistent. Most MFIs in Kosovo have NGO status. They are registered as microfinance institutions and are controlled by the Central Bank of the Republic of Kosovo (CBK) regulations. MFIs submit annual audited financial statements to $\mathrm{CBK}$ and annual reports to the NGO main office. In addition, MFIs report to the CBK on a monthly and quarterly basis. Due to their specifics, high interest rates, poor economic conditions, high unemployment rates, and informality, etc., the print and electronic media, including unclear and confusing institutional decisions state for their transformation into other forms, have created a negative perception about the role of MFI-NGOs (Boletini, 2013).

In this legal act MFIs - NGOs remain an unregulated financial category. Found in this situation, these institutions, with the support of the Ombudsman and a number of civil society organizations, address to the Constitutional Court regarding the Constitutional Review of the aforementioned law requesting the imposition of interim measures (Ombdusman, 2012). The Constitutional Court, ruling on this initiative, allows for the imposition of interim measures and suspends the application of Articles 90,95 (1.6), 110,111 and 116 of the Law on Banks, Microfinance Institutions and Non-bank Financial Institutions, Nr. 04 / L-093, dated 12 April 2012, in the same duration (Ombdusman, 2012). This situation is still going on and, despite the opinion and reasoning given in this Judgment, initiatives from time to time are taken by the higher state institutions to eliminate MFI - NGOs from the sphere of lending only because they have NGO status.

\subsection{The Current Legal Basis for the Functioning of MFI - NGO in Kosovo}

Microfinance sector is regulated by the Law on Banks, Microfinance Institutions and Non-bank Financial Institutions. This legal act following the Judgment of the Constitutional Court is also applied to MFIs - NGOs. The purpose of this general legal act is exclusively focused on the regulation, operation and development of Microfinance Institutions. On this basis, MFIs - NGOs are registered as microfinance institutions and supervised by the Central Bank of the Republic of Kosovo (CBK).

They report on a monthly and quarterly basis to the CBK, and also submit annual audited financial statements. Since most MFIs in Kosovo have NGO status, they are also regulated by the Law on Freedom of Association in Non-Governmental Organizations. And, like any other NGO, the MFIs also make appropriate annual reports to the NGO Office at the Ministry of Public Administration (AMIK, 2012). 
The Central Bank, in support of the above-mentioned Law, has so far issued a series of Regulations in the quality of sub-legal acts which currently regulate the following:

- external audit of microfinance institutions;

- internal controls and the functioning of internal audit in microfinance institutions;

- restrictions on the holding of immovable and movable property of microfinance institutions;

- credit risk management for microfinance institutions;

- liquidity risk management for microfinance institutions;

- effective interest rate and disclosure requirements for microfinance institutions; reporting of microfinance institutions;

- distribution of credit facilities to microfinance institutions and non-bank financial institutions; and

- Supplemented Rule XIV on the Licensing and Supervision of Microfinance Institutions Authorized under Sections 3, 6, and 7 of UNMIK Regulation 1999/21 (AMIK, 2012).

\subsection{Institutional Initiatives for Legal Regulation of MFI - NGOs}

Involvement of non-state actors in the social services sector is increasingly present in both developed and transition countries. NGOs ranked among the non-state actors that provide certain financial and credit services. Indeed, in transition countries, including Kosovo in particular, the social services market, where MFI - NGOs are located, is still small, unevenly developed and unattractive for the private sector. According to some indications also in developed countries, the market for social protection services is considered a market where it is not easy to win.

Notwithstanding this situation and the inability through the Law on Banks, Microfinance Institutions and Non-Banking Financial Institutions, government institutions, through various legislative forms and initiatives, are constantly trying to establish or amend the Law on Freedom of Association in Non-Governmental Organizations legal basis that would allow them, especially the MFI - NGOs, to legally transfer money from their accounts to other "institutions", including private ones (Lumezi, 2019). In these circumstances, the MFI - NGOs are concerned that once the law comes into force, millions of euros could be transferred immediately from microfinance institutions registered as NGOs into private hands within hours.

It should be noted that even with the Law on Business Organizations in Kosovo, more specifically, it is stipulated that Non-Governmental Organizations may not own (invest) capital in the legal form of a limited liability company and may not be shareholders in the joint stock company (" Law Nr. 06/L -016 on Business Organizations Article $80 \&$ article 124 ”n.d.). 
In the interpretation of these provisions, it turns out that MFI NGOs are not allowed to transform themselves into certain forms of business in the event of any own initiative, with a view to their own transformation.

\subsection{Effect of Constitutional Court Decision}

The Constitutional Court of Kosovo, in accordance with the competences conferred on it by the Constitution, is the decisive authority for total local normative control. From this point of view, it includes the control of the constitutionality of the law, the control of the constitutionality of laws and all other general legal acts in the legal order of the Republic of Kosovo, and then, the legality of all lower general acts that the law in relation to other courts. In exercising this function, the Constitutional Court is not a court that adjudicates legal and natural persons, but "laws and other general legal acts" that violate the Constitution.

The Constitutional Court is obliged to "preserve and protect" the constitutionally established relations between legal acts in the legal system of the Republic of Kosovo, which are manifested as principles of constitutionality and legality and thus to ensure harmony in the legal order by exercising normative control which, because of the complexity of the relations established in the legal order of the country, performs them through various forms and procedures for resolving so-called abstract constitutional disputes.

It is, then, with high certainty and rational action that all law-making institutions must recognize that the legal effect of the Judgment in question must be particularly in line with the still-decreed Law on Freedom of Association in Non-Governmental Organizations. If we carefully analyse the reasoning of this Judgment it turns out that the nature of these organizations has been sufficiently clarified by legitimizing the activity they exercise in the form in which they are registered.

\subsection{What Has to Be Done}

Responsible government institutions need to take timely steps to improve the outlook for MFI - NGOs by taking concrete actions to create a possible environment for their more effective and active involvement in proceedings against the financial market without any discrimination. These activities may also include the creation of mechanisms to further support the development of civil society, such as the creation of foundations to support civil society organizations in discrimination proceedings. Such a body managed by representatives of the governmental and non-governmental sector will raise funds from which to finance certain activities of non-governmental organizations in dealing with discrimination issues, such as legal case preparation and analysis, collection of materials and expenditures other necessary. Of course, such a 
foundation will need to establish clear and transparent criteria to support NGOs in litigation.

MFIs - NGOs should pay particular attention to the continuous improvement of their staff with regard to their anti-discrimination and suppression regulations, so that as many organizations as possible take on the role of interveners in individual matters against discrimination, or strengthen their ability to bring about collective compensation.

MFI - NGOs should further strengthen and streamline their activities and operations to create coalitions and networks of non - governmental organizations against discriminatory risk by enabling themselves to synergize, share roles and maximize the effect of MFI - NGO involvement in attempts and procedures that take place against their activity.

MFI - NGOs need to intensify their ranks to lobby for the creation of a legal and institutional framework for civil society development through funding and lending programs, including the creation of a foundation to support microfinance civil society organizations in the procedures of discrimination. Particular attention should be paid to strengthening the cooperation with the Ombudsperson Institution in Kosovo through timely submission of proposals for cooperation in accordance with this Institution's Platform for Cooperation with NGOs, as well as informing the Institution on the initiatives presented and requiring its involvement in proceedings as an intervener or through the oversight of legal and judicial initiatives.

Develop strategies and platforms for collaboration with law studios or similar student associations that advocate for their establishment in Kosovo's legal education institutions, where they do not exist.

\section{Conclusion}

The paper is included in a comparative analysis of the provisions of the abovementioned Laws regarding the role and activity of MFI - NGOs on one hand and government institutions on the other hand. According to above analysis we can say that certain legislative interventions, based on best comparative experience, can in no way strengthen the role of microfinance civil society organizations in this field. In addition to analysing legal decisions on the procedural roles of non-governmental organizations, the paper also aimed to highlight the key practical barriers preventing MFIs - NGOs from being more actively involved in anti-discrimination and unwanted transformation.

The main purpose of this paper is to give a contribution in the area of advancing the improvement of the legal framework and practice in Kosovo in the field of protection of MFI-NGOs. These specific organizations have in the last decade been seriously threatened by discriminatory and uninvolved actions by certain state institutions with 
the tendency for their disappearance, involuntary transformation or even with the tendency to misappropriate capital. So far, in this spirit, concrete provisions have been identified under the Law on Banks, Microfinance Institutions and Non-bank Financial Institutions, the Law on Freedom of Association in Non-Governmental Organizations and the Law on Business Organizations in Kosovo.

Initially in 2013, the Constitutional Court of the Republic of Kosovo ruled to declare unconstitutional the articles of the Law on Banks, Microfinance Institutions and NonBanking Financial Institutions (No. 04 / L-093) which in their essence enabled the transformation of MFIs. - NGOs in joint stock companies.

The upward trend of MFI - NGOs change in the last two decades has continued in two opposite directions. The former has been characterized by the tendency to transform Microfinance Institutions NGO (MFI NGO) into joint stock companies, respectively into some form of private entity, has been strongly driven by a certain number of MFI NGOs and other stakeholders and throughout the this period was repeatedly opposed by civil society in Kosovo. Second, from the activity of certain state institutions through laws and bylaws, first to block the above initiatives of MFI - NGOs and then through legal provisions their capital, not to be transformed but transferred to certain budget items and thawing them.

What is required for the consolidation and stabilization of MFI - NGOs is to continue efforts to eliminate the problematic provisions of the laws outlined above. However, advocacy activity should continue only on the basis of an in-depth analysis of the content of legal provisions, identifying constitutional and legal violations as well as violations of international principles of the right to benefit. In addition, academic and media circles need to explain the concept of MFI - NGOs by taking into account the damage that could be caused to civil society and Kosovar society in general, if they were to be transformed into private businesses or also and the eventual transfer of capital to certain items of the state budget.

It should all follow through the spirit of the Judgment of the Constitutional Court of Kosovo which is at the same time a primary and formal source of obligation for all other legal acts dealing exclusively with the role, position and activity of MFI - NGO. This, of course, relates to the materialization of the significant role that, in line with comparative experience, civil society organizations can play in ensuring effective enforcement of judicial protection against discrimination.

\section{References:}

AMIK. 2012) Regulatory Framework of MFIs.

Bank of Turkey. 2018. The determinants of Nonperforming Loans Before and After Crisis: Challenges and Policy Implications for Turkish Banks. Emerging Markets Finance and 
Trade, 54(7).

Boletini, B. 2013. Mikro - Millioneret.

Constitutional Court . 2013. Constitutional Review of Articles 90,95 (1.6), 110, 111 and 116 of the Law on Banks, Microfinance Institutions and Non-Bank Financial Institutions, No. 04/L-093, of 12 April 2012.

Güngen, A.R. 2018. Financial Inclusion and Policy-Making: Strategy, Campaigns and Microcredit a la Turca. New Political Economy, 23(3), 331-347.

Isabel Sainz-Fernandez, B. TO., Sanfilippo-Azofra, C.L.G.S. 2018. Development of the Financial Sector and Growth of Microfinance Institutions: The Moderating Effect of Economic Growth. Santander Financial Institute (SANFI), 10(11).

Khachatryan, K., Vardan Baghdasaryan Valentina Hartarska. 2019. Is the model "loans-plussavings" better for microfinance in Eastern Europe and Central Asia? A propensity score matching comparison. Review of Development Economics, 23(3).

Law Nr. 06/L -016 on Business Organizations Article $80 \&$ article 124. (n.d.).

Lumezi, A. 2019. Are Kosovo's NGOS under threat? Kosova 2.0.

Nayak, B.S., Silva, R.V. 2019. Evolution and Effects of the Legal and Regulatory Framework on Microfinance in Brazil. Latin American Policy, 10(1), 162-179.

Ombdusman. 2012. Case nr. K097/12.

Singh, S.K., Agrawal, P. 2018. An Analysis of the Microfinance as a Tool for Economic Growth. Swaranjali Publication, 1(1).

Stavrevska, E.B. 2018. The Mother, the Wife, the Entrepreneur? Women's Agency and Microfinance in a Disappearing Post-Conflict Welfare State Context. Civil Wars, 20(2), 193-216. 